\title{
Analisis performansi kolektor surya pelat datar dengan diameter lubang sirip berbeda sebagai impinging jet
}

\author{
Ketut Astawa ${ }^{1)^{*}}$, I Gusti Ngurah Putu Tenaya ${ }^{2)}$ \\ ${ }^{1,2)}$ Program STudi Teknik Mesin Universitas Udayana, Kampus Bukit Jimbaran Bali \\ Naskah diterima 20/06/2021; direvisi 22/09/2021; disetujui 30/09/2021 \\ doi: https://doi.org/10.24843/JEM.2021.v14.i02.p03
}

\begin{abstract}
Abstrak
Kolektor surya adalah sebuah alat yang mampu menyerap dan memindahkan panas dari energi matahari ke fluida kerja Kolektor surya pada umumnya, menggunakan laju aliran massa udara yang secara paralel melewati pelat penyerap, udara yang masuk inlet akan melewati pelat penyerap dan langsung keluar melalui outlet. Untuk meningkatkan performasi kolektor surya dilakukan modifikasi yaitu dengan menambahkan sirip berlubang yang divariasikan diameter lubangnya. Sirip berlubang bertujuan sebagai tempat aliran fluida panas dalam kolektor. Kolektor surya yang dipergunakan dalam penelitian ini adalah jenis kolektor surya pelat datar. Cara kerja dari kolektor surya sendiri yaitu radiasi matahari diserap oleh plat absorber dan kemudian di transfer ke fluida yang mengalir di dalam pipa di atas plat absorber. Modifikasi diameter yang dimaksudkan adalah dengan membuat diameter lubang bervariasi dari diameter besar dekat inlet ke diameter kecil dekat outlet dan dari diameter kecil dekat inlet ke diameter besar dekat outlet yang dipasang secara parallel. Variasi diameter lubang siripnya adalah $90 \mathrm{~mm}$, $70 \mathrm{~mm}, 50 \mathrm{~mm}, 30 \mathrm{~mm}$ dan $10 \mathrm{~mm}$ sedangkan penempatan sirip berlubang dilakukan secara bergantian, yaitu dari diameter besar ke kecil dan sebaliknya. Performasi yang diperoleh adalah untuk energi berguna dari diameter besar ke kecil sebesar 108,71 W sedangkan dari diameter sirip kecil ke besar 62,23 W. Untuk efisiensinya diperoleh 22,62 $\%$ untuk variasi dari diameter besar ke kecil dan sebesar 12,38 \% untuk variasi kecil ke besar.
\end{abstract}

Kata kunci: Kolektor surya pelat datar, variasi lubang sirip, performansi kolektor surya

\begin{abstract}
Solar collector is a device that is able to absorb and transfer heat from solar energy to the working fluid. Solar collectors in general, use a mass flow rate of air that is parallel to the absorbent plate, the air entering the inlet will pass through the absorbent plate and exit directly through the outlet. To improve the performance of the solar collector, modifications were made, namely by adding perforated fins with various hole diameters. The hollow fin is intended as a place for hot fluid to flow in the collector. The solar collector used in this study is a flat plate solar collector. The workings of the solar collector itself is that solar radiation is absorbed by the absorber plate and then transferred to the fluid flowing in the pipe above the absorber plate. The intended diameter modification is to make the hole diameters vary from a large diameter near the inlet to a small diameter near the outlet and from a small diameter near the inlet to a large diameter near the outlet which is installed in parallel. Variations in the diameter of the fin holes are $90 \mathrm{~mm}, 70 \mathrm{~mm}, 50 \mathrm{~mm}, 30 \mathrm{~mm}$ and $10 \mathrm{~mm}$ while the placement of the perforated fins is done alternately, from large to small diameter and vice versa. The performance obtained is for useful energy from large to small diameter of $108.71 \mathrm{~W}$ while from small to large fin diameter $62.23 \mathrm{~W}$. For efficiency it is obtained $22.62 \%$ for variations from large to small diameter and $12.38 \%$ for small to large variations.
\end{abstract}

Key words: Flat plate solar collector, variation of fin holes, performance of solar collector

\section{Pendahuluan}

Kebutuhan akan energi yang terus meningkat dan semakin menipisnya cadangan minyak bumi, mendorong manusia untuk mencari sumber sumber energi alternatif. Semakin meningkatnya kesadaran manusia akan pentingnya lingkungan yang bersih, sehat dan bebas dari polusi mengarahkan manusia pada energi alternatif yang tidak hanya terbaharukan (renewable energy) tetapi juga bersahabat dengan lingkungan. Pencarian itu mengarahkan manusia pada pemanfaatan energi matahari baik secara langsung maupun tidak langsung. Salah satu cara pemanfaatan energi matahari secara langsung adalah dengan menggunakan kolektor surya. dan salah satu contoh pemanfaatan energi surya secara langsung adalah untuk pengeringan.

Kolektor surya adalah sebuah alat yang mampu menyerap dan memindahkan panas dari energi matahari kefluida kerja [1]. Ada beberapa tipe kolektor surya, salah satu diantaranya yang sudah banyak dikenal adalah kolektor surya pelat datar. Jenis kolektor ini menggunakan pelat berupa lembaran, dimana untuk mendapatkan hasil yang optimal permukaan kolektor dicat warna hitam, tujuannya untuk mendapatkan penyerapan radiasi matahari yang optimal dan selanjutnya 
kalor ditransfer ke fluida kerja [2]. Untuk menjaga agar tidak terjadi kerugian panas ke lingkungan, maka digunakan penutup transparan sehingga terjadi efek rumah kaca, sedangkan pada bagian bawah dan samping diberikan isolasi.

Penelitian terdahulu telah meneliti dan mengembangkan kolektor surya, seperti yang sudah pernah dilakukan tentang performansi kolektor surya pelat datar dengan aliran di bawah pelat berlubang dengan variasi diameter berbeda [3]. Berbekal dari penelitian tersebut, maka penulis ingin melakukan modifikasi kolektor surya pelat datar yang bertujuan untuk dapat meningkatkan performa dari kolektor surya ini yaitu dengan merubah pelat sirip berlubang dengan diameter bervariasi yang dipasang secara parallel dibagian bawah pelat penyerap.

\subsection{Jenis-jenis Perpindahan Panas}

Prinsip kerja kolektor surya pelat datar adalah memindahkan radiasi matahari ke fluida kerja. Radiasi matahari yang jatuh pada cover kaca sebagian akan langsung dipantulkan, kemudian sebagiannya akan diserap, dan sebagiannya lagi akan diteruskan ke pelat penyerap. Radiasi yang sampai pada pelat penyerap akan diserap panasnya oleh pelat penyerap. Panas yang diserap oleh pelat penyerap akan digunakan untuk memanaskan fluida kerja yang berupa udara mengalir. Untuk proses perpindahan panas dari radiasi matahari sampai pada fluida kerja terjadi melalui tiga mekanisme perpindahan panas yaitu, konduksi, konveksi, dan radiasi. Secara konduksi, terjadi pada udara yang diam dan pada pelat penyerap. Secara konveksi, terjadi antara permukaan pelat penyerap dengan fluida kerja yang mengalir. Kemudian pertukaran panas radiasi terjadi diatas penutup transparan, diantara penutup transparan dengan pelat penyerap bagian atas, dan antara pelat penyerap bagian bawah dengan permukaan isolasi [4].

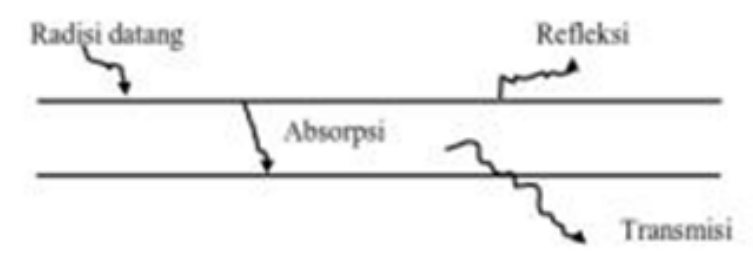

\section{Gambar 1. Bagan pengaruh radiasi dating [4]}

Bila energi radiasi menimpa permukaan suatu media, maka sebagian energi radiasi tersebut akan di pantulkan (refleksi), sebagian akan diserap (absorpsi), dan sebagian lagi akan diteruskan (transmisi), seperti ditunjukan pada Gambar 1.

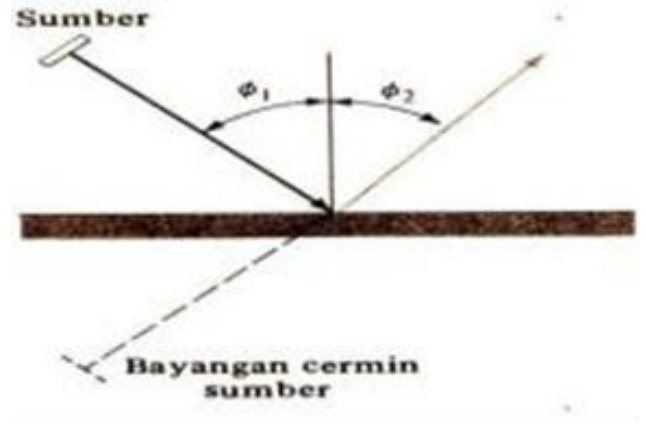

(a)

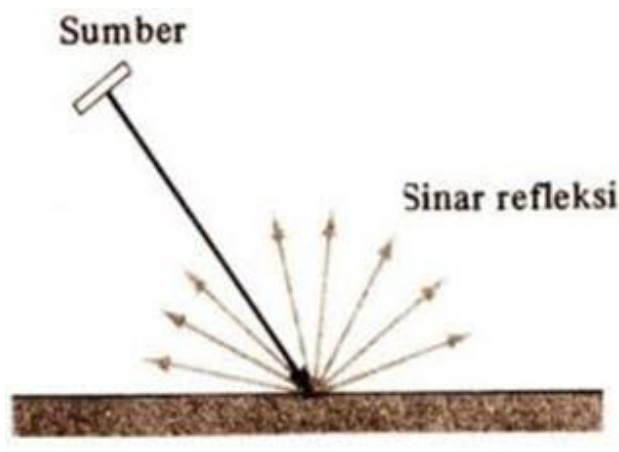

(b)

Gambar 2. Refleksi cahaya (a) Spekular, (b) Baur [5]

Jika $\rho$ disebut refleksifitas, disebut absorptivitas $(\alpha)$, disebut transmitivitas $(\tau)$, maka $(\alpha)$ hubungan ketiganya adalah: $\rho+\alpha+T=1$ Karena benda padat tidak meneruskan radiasi termal, maka transmisivitas dianggap nol, sehingga $\rho+\rho=1$. Ada dua fenomena refleksi yang dapat diamati bila radiasi menimpa suatu permukaan. Jika sudut jatuhnya sama dengan sudut refleksi, maka dapat dikatakan refleksi itu spekular (specular). Di lain pihak, apabila berkas yang jatuh itu tersebar merata ke segala arah sesudah refleksi maka refleksi itu disebut baur (diffuse). Radiasi surya (solar radiation) merupakan suatu bentuk radiasi thermal yang mempunyai distribusi panjang gelombang khusus. Intensitasnya sangat bergantung dari kondisi atmosfer, saat dalam tahun, dan sudut timpa (angle of incidence) sinar matahari dipermukaan bumi. Pada batas luar atmosfer, iradiasi surya total ialah $1395 \mathrm{~W} / \mathrm{m} 2$ bilamana bumi berada pada jarak rata-ratanya dari matahari. Angka ini disebut konstanta surya (solar constant). Tidak seluruh energi yang disebutkan dalam konstanta surya mencapai permukaan bumi, karena terdapat absorpsi yang kuat dari karbondioksida dan uap air di atmosfer. Radiasi surya yang menimpa permukaan bumi juga bergantung dari kadar debu dan zat pencemar lainnya dalam atmosfer. Energi surya yang maksimum akan mencapai permukaan bumi bilamana berkas sinar itu langsung menimpa permukaan bumi, karena terdapat bidang pandang yang lebih luas terhadap fluks surya yang datang dan berkas sinar surya menempuh jarak yang 
lebih pendek di atmosfer, sehingga mengalami absorpsi lebih sedikit daripada jika sudut timpanya miring terhadap normal.

Releksi spekular memberikan bayangan cermin dari sumber itu kepada pengamat. Tetapi tidak ada permukaan yang sebenarnya yang hanya spekular atau baur. Sebuah cermin biasa tentu bersifat spekular untuk cahaya tampak tetapi belum tentu bersifat spekular untuk keseluruhan rentang panjang gelombang radisi termal. Biasanya, permukaan kasar lebih menunjukkan sifat baur dari pada permukaan yang mengkilap.

\subsection{Bagian-bagian Kolektor Datar}

Adapun krakteristik bagian-bagian penting dari kolektor surya pelat datar ditunjukkan pada Gambar 3, terdiri dari [5]:

a. Penutup transparan

Penutup transparan di harapkan memiliki sifat transmisivitas yang tinggi dan sifat absorsivitas serta refleksivitas serendah mungkin. Refleksivitas (daya pantul) tergantung pada indek bias dan sudut datang yang dibentuk oleh sinar datang terhadap garis normal permukaan. Sedangkan transmisivitas suatu permukaan dapat mempengaruhi intensitas energi matahari yang diserap oleh pelat penyerap. Transmisivitas kaca akan menurun bila sudut datangnya melebihi $45^{\circ}$ terhadap vertical. Sedangkan absorsivitas akan bertambah sebanding dengan panjang lintasan pada penutup transparan, sehingga bagian yang diteruskan menjadi berkurang.

b. Pelat penyerap

Pelat penyerap yang ideal memiliki permukaan dengan tingkat absorsivitas yang tinggi guna menyerap radiasi matahari sebanyak mungkin dan tingka temisivitas yang serendah mungkin agar kerugian panas karena radiasi balik sekecil mungkin disamping itu pelat penyerap diharapkan memiliki konduktivitas thermal $(\mathrm{K})$ yang tinggi.

c. Isolasi

Merupakan material dengan sifat konduktivitas termal (K) rendah, dipergunakan untuk menghindari terjadinya kehilangan panas kelingkungan.

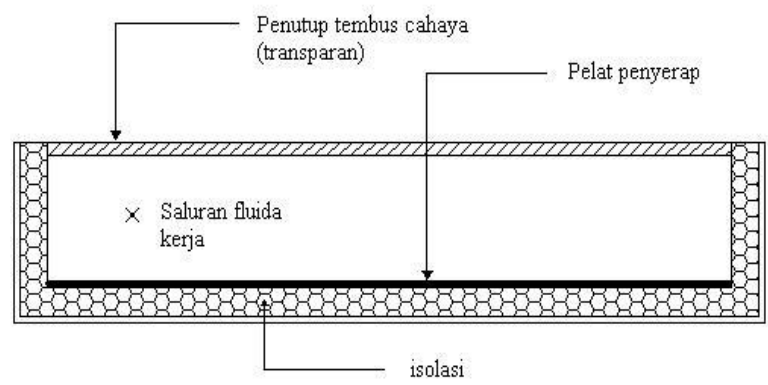

Gambar 3. Kolektor surya pelat datar [6]

\subsection{Kolektor Surya Pelat Datar dengan Aliran} Impinging Jet

Untuk menciptakan aliran Impinging Jets sehingga menimpa pelat penyerap tersebut maka pada kolektor surya ini ditambahkan pelat berlubang yang berfungsi sebagai nosel diantara pelat penyerap dan pelat bagian bawah. Perpindahan panas dengan menggunakan metoda aliran Impinging Jet, merupakan perpindahan panas dimana fluida dipancarkan melalui lubanglubang menuju permukaan/pelat yang memiliki perbedaan temperature [7]. Metoda ini telah diterapkan pada berbagai komponen seperti sudu turbin, dinding ruang pembakaran, heat exchanger dan komponen elektronik. "impinging" disini berarti "tabrakan", dimana terjadi tabrakan antara fluida pendingin dengan permukaan suatu target dalam kecepatan aliran yang tinggi. Sebaliknya, cara ini juga dapat digunakan untuk memanaskan suatu komponen atau suatu bahan tertentu contohnya pada proses pengeringan kertas dan pengeringan tekstil.

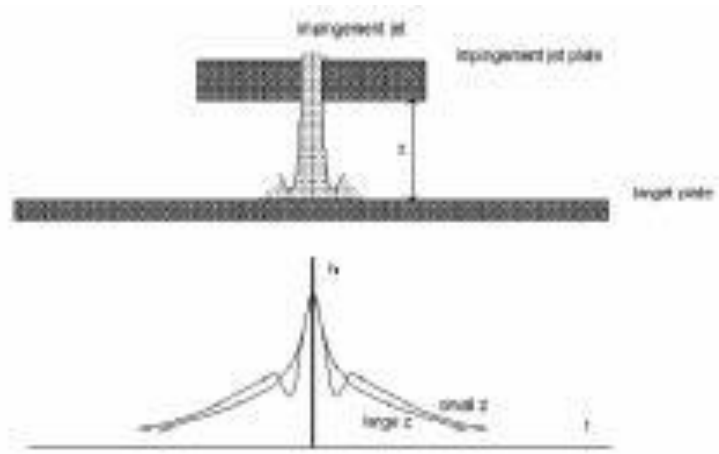

(a)

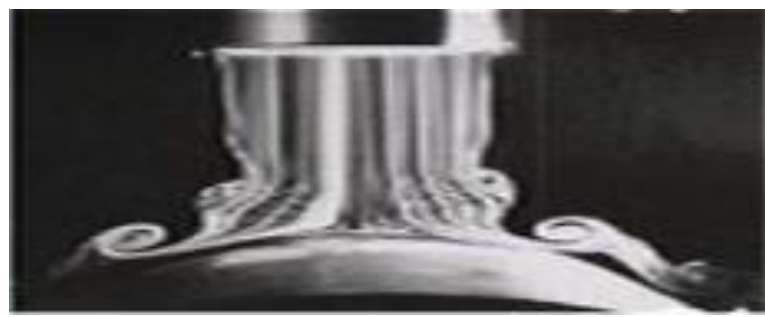

(b)

Gambar 4. (a) Mekanisme perpindahan panas impinging jet (b) Visualisasi impinging jet [7]

Pada Gambar 4 (a, b) ditunjukkan visualisasi impinging jet, terlihat bahwa koefisien perpindahan panas akan menurun seiring dengan meningkatnya radius (jarak dari inti jet), selain itu akan terjadi puncak koefisien perpindahan panas yang kedua untuk jarak jet nosel yang cukup dekat dengan permukaan target ( $\mathrm{H}$ yang kecil) [7].

Awalnya penelitian terhadap metoda peningkatan perpindahan panas impinging jet ini terfokus pada penggunaan impinging jet tunggal, kemudian berkembang pada penggunaan susunan impinging jet. Untuk impinging jet tunggal, sepert Gambar 4, aliran udara pendingin keluar melalui 
sebuah jet nosel dan langsung menabrak permukaan target.

Aliran udara yang memancar memiliki kecepatan tertentu dan setelah terjadi tabrakan dengan permukaan target akan mengakibatkan terjadinya aliran turbulen. Hal ini mengakibatkan adanya peningkatan yang signifikan laju perpindahan panas yang terjadi. Koefisien perpindahan panas (h) yang tertinggi dihasilkan pada inti jet (semburan) dan akan menurun untuk daerah diluar inti jet [7]

\subsection{Kolektor Surya Pelat Datar Menggunakan \\ Aliran Impinging Jets dengan Variasi \\ Diameter Nosel}

Kolektor surya ini memiliki rancangan yaitu menggunakan pelat berlubang yang berfungsi sebagai nosel dengan diameter lubang yang bervariasi dari diameter lubang besar (dekat inlet) ke diameter lubang kecil (dekat outlet). Fluida yang mengalir pada kolektor ini berada didepan pelat berlubang, sedangkan pada bagian atas pelat penyerap fluida dikondisikan diam. Pada kolektor ini juga akan ditambahkan pelat bawah diatas permukaan isolasi bagian bawah.

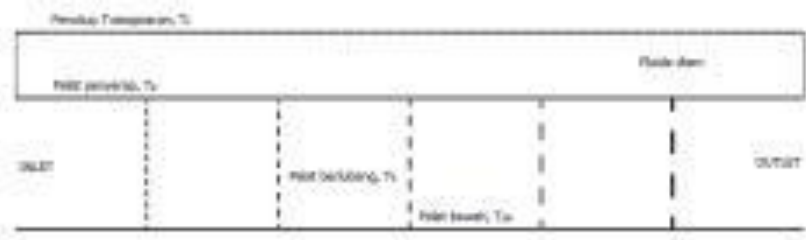

Gambar 5. Kolektor surya aliran impinging jets dengan diameter nosel bervariasi

\subsection{Energi berguna kolektor surya}

Untuk perhitungan energi yang diserap atau energi yang berguna pada kolektor surya dapat digunakan persamaan [5]:

$$
\dot{Q}_{u, a}=\dot{m}_{\text {out }} c_{p}\left(T_{0}-T_{i}\right)
$$

dimana :

$$
\begin{aligned}
& Q_{u a}=\text { energi berguna kolektor } \\
& \text { sebenernya tiap satuan luas (watt) } \\
& \dot{m}_{\text {out }}=\text { laju aliran massa fluida yang } \\
& \text { keluar dari kolektor surya }(\mathrm{kg} / \mathrm{s}) \\
& c_{p} \quad=\text { panas jenis fluida }(\mathrm{J} / \mathrm{kg} . \mathrm{K}) \text {, nilai } c_{v} \\
& \text { didapat dari properties } \\
& \text { fluida berdasarkan temperature } \\
& \left(T_{\text {film }}=\frac{T_{0}+T_{\mathrm{i}}}{\imath}\right) \\
& T_{i} \quad=\text { temperatur fluida masuk }(\mathrm{K}) \\
& T_{0} \quad=\text { temperatur fluida keluar }(\mathrm{K})
\end{aligned}
$$

\subsection{Analisa Performansi}

Efisiensi kolektor surya merupakan perbandingan panas yang diserap oleh fluida atau energi berguna dan intensits matahari yang mengenai kolektor. Performansi dari kolektor dapat dinyatakan dengan efisiensi thermalnya. Akan tetapi, intensitas radiasi matahari berubah terhadap waktu.

Dalam penelitian ini pengujian dilakukan hanya untuk menentukan performansi dari kolektor saja. Metode yang digunakan adalah Instantaneous efficiency atau efisiensi sesaat adalah efisiensi keadaan steady untuk selang waktu tertentu. Sehingga efisiensi aktual dari kolektor dapat ditentukan dengan menggunakan persamaan berikut [5]:

$$
\eta_{a}=\frac{Q_{u, a}}{A_{c} I_{T}}
$$

Dimana :

$$
\begin{aligned}
& \eta_{a}= \text { efisiensi aktual kolektor (\%) } \\
& Q_{u, a}= \text { energi berguna kolektor } \\
& \text { sebenarnya tiap satuan luas (watt) } \\
& A_{c} \quad=\begin{array}{l}
\text { luas bidang penyerapan kolektor } \\
\left(\mathrm{m}^{2}\right)
\end{array} \\
& I_{\tau} \quad \begin{array}{l}
\text { = radiasi surya yang jatuh pada } \\
\text { bidang kolektor (watt } \left./ \mathrm{m}^{2}\right)
\end{array}
\end{aligned}
$$

\section{Metode Penelitian}

Penelitian yang dilakukan adalah penelitian dengan metode eksperimental, yaitu dimulai dengan pembuatan kolektor surya pelat datar dengan aliran impinging jet yang menggunakan pelat berlubang dengan diameter lubang bervariasi (dari lubang yang lebih besar ke lubang yang lebih kecil) yang disusun secara paralel dibawah pelat penyerap yang selanjutnya dipasang alat pengukur di titik-titik tertentu pada kolektor. Setelah persiapan selesai maka dilakukan pengujian pada kolektor surya dengan cara pengamatan dan pencatatan data-data yang ditunjukkan oleh alat ukur. Setelah mendapatkan data-data yang aktual dari kolektor surya tersebut maka temperatur keluar kolektor diukur dan energi berguna dan effisiensi dihitung secara aktual. Kemudian dari analisis tersebut dapat ditarik kesimpulan mengenai performa kolektor surya pelat datar menggunakan aliran impinging jet dengan aliran langsung pada pelat berlubang dengan diameter lubang yang bervariasi.

\subsection{Kontruksi Kolektor Surya Aliran Impinging Jets dengan Diameter Lubang Bervariasi}

Kontruksi dari kolektor surya dengan diameter lubang bervariasi ini hampir sama dengan konstruksi kolektor surya dengan diameter lubang yang sama yaitu terdiri dari cover transparan, pelat penyerap, pelat berlubang, pelat bawah, dan isolasi. Pada kolektor ini terdapat dua saluran udara yaitu satu saluran untuk udara mengalir (fluida kerja) dan satu saluran untuk udara yang dikondisikan diam.

Kondisi udara mengalir berada di antara pelat penyerap dan pelat bagian bawah, sedangkan 
untuk kondisi udara diam berada di antara kaca bening dan pelat penyerap. Untuk lebih jelasnya konstruksi kolektor surya dengan penambahan pelat berlubang dapat dilihat pada Gambar 6.

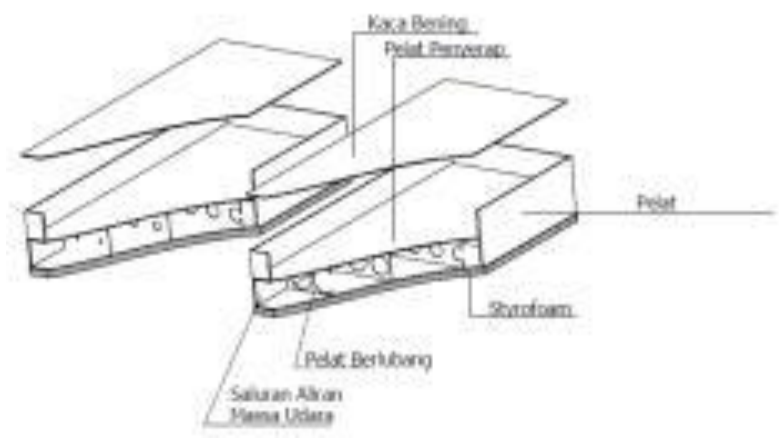

Gambar 6. Konstruksi kolektor surya menggunakan aliran impinging jets

Pada penelitian ini kolektor surya pelat datar ditambahkan pelat berlubang dengan diameter lubang bervariasi. Panjang pelat $L p=1200 \mathrm{~mm}$ dan Lebar kolektor $\mathrm{Wp}=500 \mathrm{~mm}$. Diameter pelat berlubang dari diameter besar ke diameter kecil yaitu $90 \mathrm{~mm}, 70 \mathrm{~mm}, 50 \mathrm{~mm}, 30 \mathrm{~mm}$ dan $10 \mathrm{~mm}$. Sedangkan diameter berlubang dari diameter kecil ke besar yaitu $10 \mathrm{~mm}, 30 \mathrm{~mm}, 50 \mathrm{~mm}, 70 \mathrm{~mm}, 90$ $\mathrm{mm}$. Jarak antara pelat berlubang $200 \mathrm{~mm}$. Kontruksi pelat berlubang ditunjukkan pada Gambar 7.

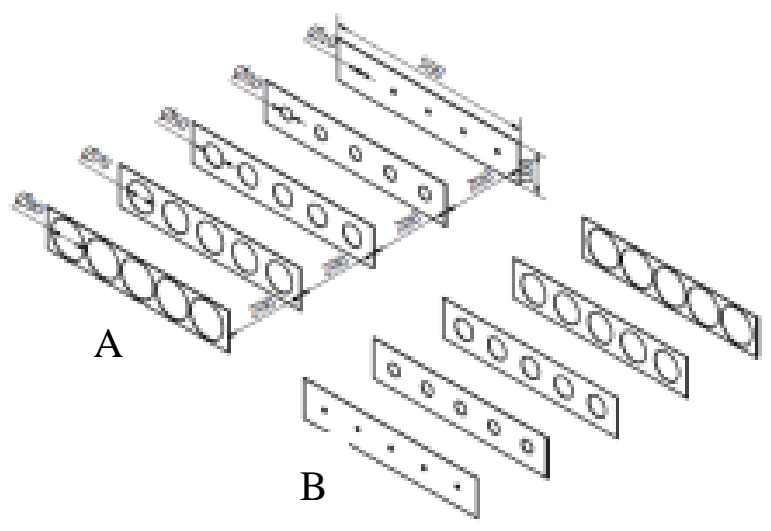

Gambar 7. Konstruksi pelat berlubang dengan diameter bervariasi $(A)$ Depan dan

(B) Belakang

Pelat penyerap, pelat berlubang dan pelat bawah menggunakan pelat besi dengan ketebalan $1,2 \mathrm{~mm}$ yang dicat hitam doff. Untuk penutup transparannya menggunakan kaca bening dengan ketebalan sebesar $5 \mathrm{~mm}$. Pada bagian bawah dan samping diberi isolasi yang terdiri dari gabus (styrofoam) dengan ketebalan $10 \mathrm{~mm}$ dan triplek dengan ketebalan $4 \mathrm{~mm}$. Jarak antara kaca dengan pelat penyerap $\mathrm{N}=5 \mathrm{~cm}$ dan saluran udara di antara pelat penyerap dan pelat bagian bawah dengan jarak yaitu $5 \mathrm{~cm}$.

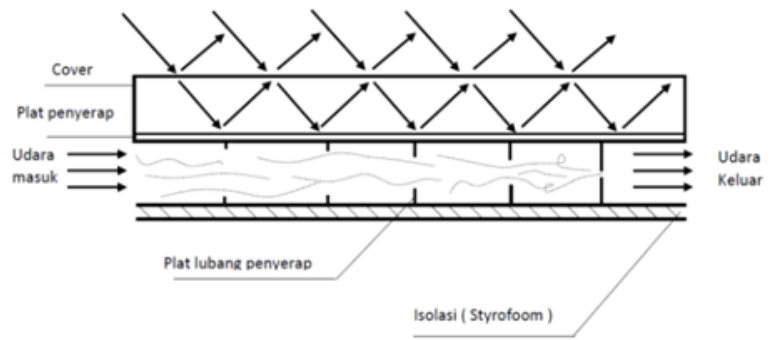

Gambar 8. Aliran udara pada kolektor surya aliran impinging jets (a) diameter besar ke diameter kecil

\subsection{Pengujian Kolektor Surya Pelat datar}

Pengujian dilakukan dengan merangkai komponen-komponen yang diperlukan dalam pengambilan data dan meletakkan kolektor surya ini di tempat datar dan mendapatkan sinar matahari. Agar udara dapat mengalir di dalam kolektor dan menciptakan aliran impinging jets digunakan aliran paksa dengan bantuan blower. Untuk rancangan pengujian kolektor tersebut ditunjukkan pada Gambar 9 [3].

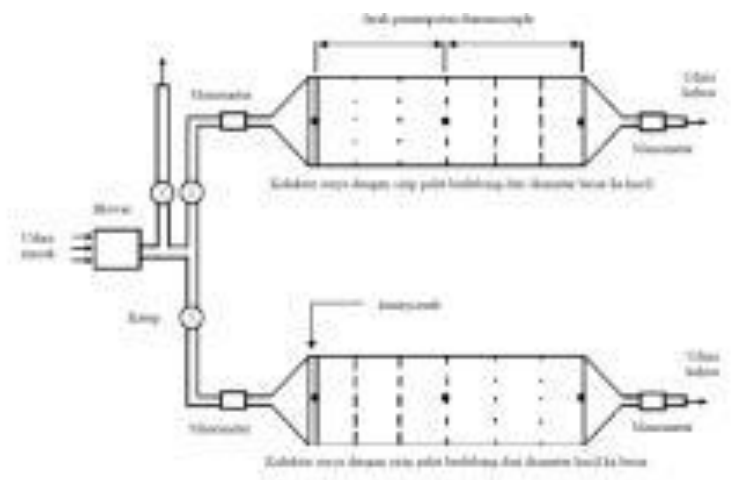

Gambar 9. Rancangan pengujian kolektor surya [8]

\section{Hasil dan Pembahasan}

Untuk dapat menganalisa besar efisiensi dari kolektor surya dengan variasi sirip berlubang dengan diameter berbeda (diameter kecil ke diameter besar dan diameter besar ke diameter kecil) yang dipasang secara parallel, maka dilakukan perhitungan terhadap data-data yang didapat dari salah satu data hasil pengujian pada setiap kolektor surya pada pengukuran pukul 12.00 Wita. dimana intensitas matahari terukur dari solar powermeter $\left(I_{T}\right)$ sebesar $1,211 \mathrm{~W} / \mathrm{m}^{3}$.

Kolektor Surya Dengan Sirip Berlubang Diameter Kecil - Besar, pada Temperatur fiuida:

$T_{\text {fluida }}=\frac{T_{i}+T_{\text {out }}}{2}=\frac{309+319}{2}=314 \mathrm{~K}$

Besarnya $\mathrm{Cp}=1,00756 \mathrm{~kJ} / \mathrm{kg} \cdot \mathrm{K}=1007,56 \mathrm{~J} / \mathrm{kg} \cdot \mathrm{K}$

Sehingga besarnya energi berguna kolektor:

$Q_{u, a}=\dot{m} . C p\left(T_{o u t}-T_{i n}\right)$ 


$$
=0,008 \times 1007,56(319-309)=80,6048 \mathrm{~W}
$$

Besarnya Efisiensi Kolektor:

$\eta_{a}=\frac{Q_{u, a}}{A_{c} I_{T}} \times 100 \%=\frac{80,6048 \mathrm{~W}}{0,6 \mathrm{~m}^{2} 1,1211 \mathrm{~W} / \mathrm{m}^{2}}=11,093 \%$

Kolektor Surya Dengan Sirip Berlubang Diameter Besar - Kecil, pada temperatur fluida:

$T_{\text {fluida }}=\frac{T_{i}+T_{\text {out }}}{2}=\frac{305+321}{2}=313 \mathrm{~K}$

Besarnya $\mathrm{Cp}=1,00752 \mathrm{~kJ} / \mathrm{kg} \cdot \mathrm{K}=1007,52 \mathrm{~J} / \mathrm{kg} \cdot \mathrm{K}$ Sehingga energi Berguna aktual:

$$
\begin{aligned}
Q_{u, a} & =\dot{m} . C p\left(T_{\text {out }}-T_{\text {in }}\right) \\
& =0,008 \times 1007,53(321-305) \\
& =128,962 \mathrm{~W}
\end{aligned}
$$

Effisiensi kolektor:

$\eta_{a}=\frac{Q_{u, a}}{A_{c} I_{T}} \times 100 \%=\frac{128,962 \mathrm{~W}}{0,6 \mathrm{~m}^{2} 1,1211 \mathrm{~W} / \mathrm{m}^{2}}=17,748 \%$

\subsection{Analisa Temperatur Keluar ( $\left.T_{\text {out }}\right)$}

Perbandingan kolektor surya pelat datar dengan sirip berlubang diameter kecil - besar dan sirip berlubang diameter besar - kecil dapat ditunjukkan pada Gambar 10.

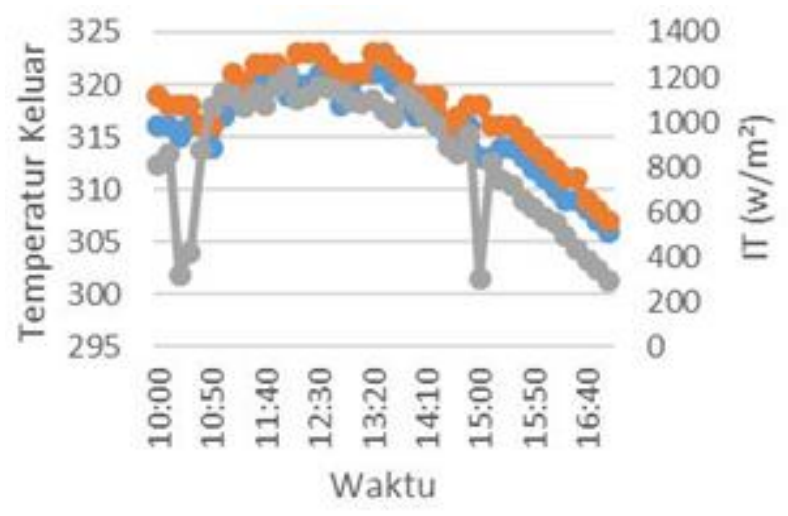

\section{$\Longrightarrow$ Tout o-O $(\mathrm{K}) \longrightarrow$ Tout $\mathrm{O}-\mathrm{o}(\mathrm{K}) \longrightarrow \mathrm{T}\left(\mathrm{w} / \mathrm{m}^{3}\right)$}

Gambar 10. Grafik perbandingan temperatur keluar ( $T_{\text {out }}$ ) kolektor terhadap waktu diameter kecil-besar

Pada Gambar 10 dapat dilihat bahwa temperatur keluar kolektor dengan sirip berlubang diameter besar-kecil lebih tinggi dibandingkan dengan temperatur keluar kolektor dengan sirip berlubang diameter kecil - besar. Hal tersebut disebabkan pada kolektor dengan sirip berlubang diameter besar - kecil, distribusi panas yang terjadi lebih cepat atau besar dikarenakan fluida yang mengalir melalui lubang-lubang sirip dari lubang yang besar menuju lubang-lubang yang semakin kecil sehingga temperatur keluarannya menjadi tinggi. Pada grafik dapat dilihat juga bahwa intensitas radiasi matahari yang tidak konstan yang dipengaruhi oleh faktor cuaca menyebabkan temperatur keluaran kolektor menjadi naik dan turun.

\subsection{Analisa Energi Berguna $\left(Q_{u, a}\right)$ Kolektor Pelat Datar}

Gambar 11 menunjukkan energi berguna pada kolektor dengan sirip berlubang diameter besar - kecil lebih tinggi dari pada kolektor dengan sirip berlubang diameter kecil - besar. Hal ini disebabkan karena volume fluida yg berbeda. Fluida yang mengalir melalui lubang sirip berdiameter besar menuju lubang-lubang yang semakin kecil akan mendapatkan temperatur panas keluaran yang lebih besar. Hal ini menunjukkan bahwa besarnya energi berguna yang dihasilkan merupakan fungsi dari laju aliran massa kolektor, koefisien panas jenis udara dan temperatur udara keluar kolektor. Semakin besar temperatur panas keluaran pada kolektor maka energi berguna yang didapat akan semakin besar. Dan semakin besar selisih antara udara keluaran kolektor dengan udara masuk kolektor akan mempengaruhi energi berguna kolektor juga semakin besar.

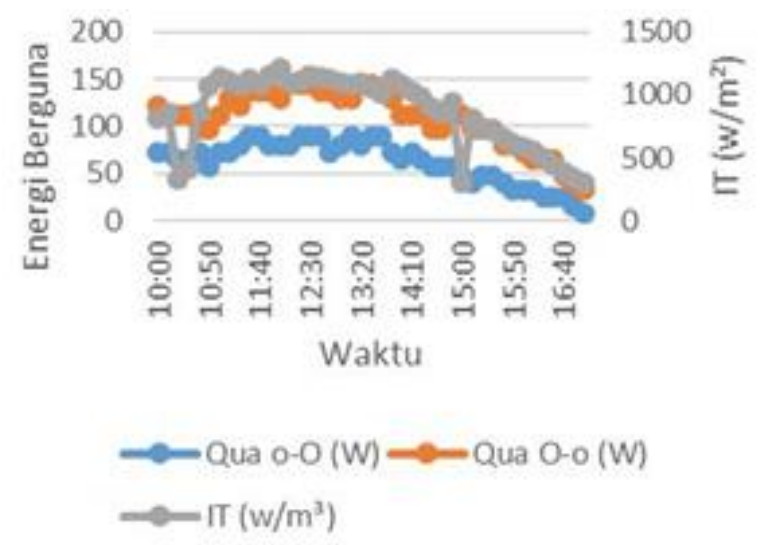

Gambar 11. Grafik perbandingan energi berguna $\left(Q_{u, a}\right)$ terhadap waktu

\subsection{Efisiensi $\left(\eta_{a}\right)$ Kolektor Pelat Datar}

Efisiensi Kolektor surya pelat datar dengan aliran Impinging Jet yang diperoleh dari hasil perhitungan ditunjukkan pada Gambar 12. Dari Gambar 12 dapat dilihat bahwa efisiensi kolektor dengan variasi diameter sirip dari lubang besar ke kecil lebih tinggi dibandingkan dengan kolektor dengan variasi dari diameter kecil ke besar, hal ini disebabkan karena aliran fluida masuk (udara) lebih banyak masuk pada variasi diameter besar ke kecil dan keluarnya semakin sedikit atau melambat sehingga udara dalam kolektor menyerap panas lebih lama dan temperatur udara keluar kolektor juga menjadi semakin tinggi dan efisiensinya pun menjadi tinggi. 


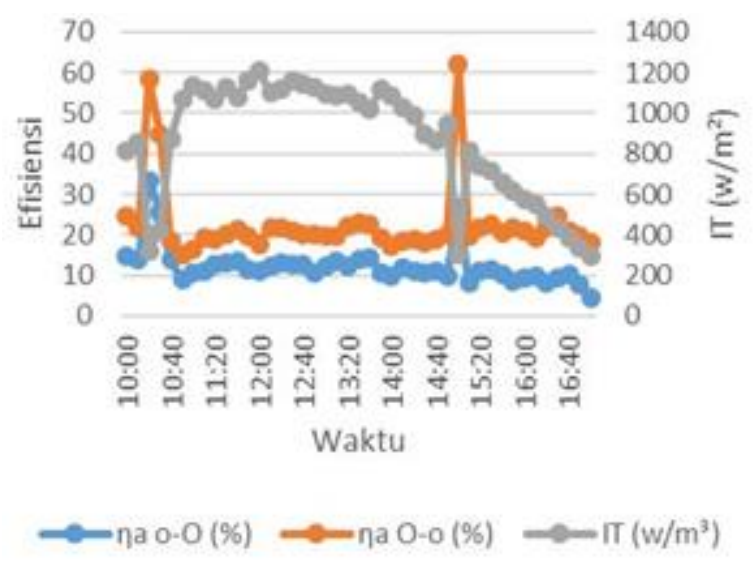

Gambar 12. Grafik perbandingan efisiensi $\left(\eta_{a}\right)$ kolektor terhadap waktu

\section{Simpulan}

Dari hasil pengujian yang telah dilaksanakan maka dapat disimpulkan bahwa kolektor surya pelat datar sebagai Impinging Jet dengan variasi diameter lubang dari diameter besar ke kecil menghasilkan temperatur keluar yang lebih tinggi dan menyebabkan energi bergunanya juga lebih tinggi sehingga efisiensi hariannya menjadi lebih tinggi dibandingkan dengan kolektor surya pelat datar dengan variasi diameter dari kecil ke besar.

\section{Daftar Pustaka}

[1] Astawa dan M. Sucipta, Pembelajaran Energi Surya dengan Menggunakan Metode Problem Based Learning, Dana PHK-I Universitas Udayana, 2010.

[2] Astawa, Sukadana dan Wika, Analisa Performansi Kolektor Surya Pelat Datar untuk Pemanas Air dengan Variasi Ketebalan Kaca Penutup, Jurnal Teknik Mesin Indonesia, Volume 5 No.2, ISSN 1907-350X. pp 118121, 2010.

[3] Sudarpa, I Made, Analisa Performansi Kolektor Surya Pelat Datar Menggunakan Aliran Impinging Jet dengan Aliran Dibawah Pelat Berlubang dengan Variasi Diameter Berbeda.Bali: Universitas Udayana, 2012.

[4] Incropera, F. P., and De Witt, D. P, Fundamental of Heat and Mass Transfer. Singapore: John Wiley \& Sons, Inc, 1994.

[5] Duffie, J. A., and Backman. 1991. Solar Enggenering of Thermal Process, $2^{\text {nd }}$ ed. New York: John Wiley \& Sons, Inc, 1991.

[6] [6] Astawa, Gunawan dan Hendra, Analisa Kolektor Surya Pelat Datar dengan Media Penyimpan Panas Pasir untuk Pemanas Udara, Jurnal IImiah TEKNIKA, Volume 10. No 1, edisi Juli 2014. ISSN 1693-024X. pp 4350, 2014.

[7] Yunianto Bambang, Analisa Transient Perpindahan Panas pada Heat Plate dengan
Metode Confined Impinging Jet. Semarang. Undip, 2005.

[8] Wibawa, A.S.,Analisa Performan Kolektor Surya Pelat Datar Menggunakan Aliran Impinging Jet dengan Aliran Dibawah Pelat Berlubang, Universitas Udayana, 2012.

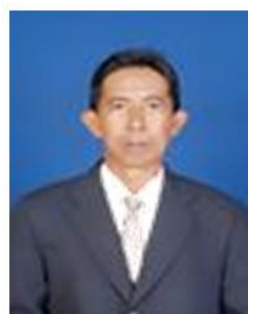

Ketut Astawa, menyelesaikan studi S1 di Universitas UdayanaBali, kemudian melanjutkan program magister teknik di Jurusan Teknik Mesin Universitas Brawijaya dan lulus pada tahun 2006, Bidang penelitian yang diminati adalah Heat transfer dan Konversi Energi. 